\title{
PERUBAHAN KURIKULUM DAN PENDIDIKAN PROFESI GURU: UPAYA MENEMUKAN ARAH PENDIDIKAN YANG IDEAL ATAU KONSTELASI KEKUASAAN?
}

\author{
Apri Damai Sagita Krissandi ${ }^{1}$, Kelik Agung Cahya Setiawan ${ }^{2}$ \\ Program Studi PGSD Universitas Sanata Dharma Yogyakarta ${ }^{1}$, \\ Program Studi Pendidikan Bahasa dan Sastra Indonesia Universitas Negeri Yogyakarta ${ }^{2}$ \\ E-mail: apridamai@gmail.com ${ }^{1}$, keliksky49@gmail.com²
}

\begin{abstract}
Abstrak
Tujuan penelitian ini untuk membahas kebijakan program profesi guru dalam hal mutu pendidikan atau hanyalah konstelasi kekuasaan semata. Metode penelitian yang digunakan adalah penelitian deskriptif dengan studi dokumen. Program PPG baik prajabatan maupun dalam jabatan terkandung konstelasi kekuasaan di dalamnya. Hal ini dapat dilihat dari beberapa catatan pertama tidak ada tindak lanjut dari program PPG. Kedua dari hasil wawancara yang dilakukan penulis didapati bahwa materi yang diberikan dalam program ini tidak berbeda dengan meteri yang diberikan di universitas. Ketiga adalah PPG prajabatan, tujuan dari PPG prajabatan tidak lain adalah untuk meningkatkan kualitas calon guru sesuai dengan indikator-indikator yang ditetapkan dalam program tersebut. Yang menadi pertanyaan adalah apakah selama ini universitas keguruan dan ilmu pendidikan tidak membekali mahasiswanya untuk menjadi guru yang berkualitas? jika memang universitas keguruan dan ilmu pendidikan tidak membekali masiswa untuk menjadi guru berkualitas, kenapa tidak memperbaiki konsep dan pembelajaran dalam perkuliahan disetiap universitas tersebut, namun malah menambah program baru. Keempat tidak ada program sejenis di negara-negara yang maju pendidikanya seperti Finlandia, Korea Selatan, Jepang dan seterusnya. Kelima tes yang digunakan dalam seleksi masuk hanya menggunakan tes yang secara tidak langsung hanya mengukur tingkat kognitif saja.
\end{abstract}

Kata kunci: Kebijakan Pendidikan, Kurikulum, Perubahan kurikulum, Program Profesi guru, Konstelasi Kekuasaan.

Abstract
The purpose of this research is to review the teacher certification program (PPG) policy as an
improvement in educational quality or merely a constellation of power. The method used is a descriptive
research method with documentary analysis. The PPG program, both pre-service and in-service,
contains a constellation of power. It can be seen from some notes. Firstly, there is no follow-up from
the PPG program. Secondly, the results of interviews by the researchers reveal that the materials
provided in this program are not different from those given at the university. Thirdly, even though PPG
pre-service is aimed at improving the quality of prospective teachers based on the indicators specified
in the program, why do teacher training and education universities not prepare their students to be
quality teachers? if they do not do so, why they do not improve the concepts and learning in lectures at
their respective universities instead of adding new programs. Fourthly, there are no similar programs
in countries with quality education, such as Finland, South Korea, Japan and so on. Fifthly, the tests in
the admission process only administer tests that indirectly measure the cognitive level.

Keywords: Education Policy, Curriculum, Curriculum Change, Teacher Certification Program, Constellation of Power

\section{PENDAHULUAN}

Pendidikan pada hakikatnya merupakan suatu upaya sadar untuk menyiapkan sumber daya manusia dalam mengembangkan potensi untuk menghadapi kehidupan di masa sekarang maupun masa depan. Seperti yang diungkapkan dalam Undang-undang Sistem Pendidikan Nasional nomor 20 tahun 2003 pasal 1 ayat (1), pendidikan adalah usaha sadar dan terencana untuk mewujudkan suasana belajar dan proses pembelajaran agar peserta didik secara aktif dapat mengembangkan potensi diri sehingga 
memiliki kekuatan spiritual baik keagamaan, pengendalian diri dalam masyarakat, berbangsa dan bernegara.

Kurikulum merupakan salah satu unsur dalam membentuk bagaimana pendidikan itu berlangsung. Kurikulum sendiri menurut [1] adalah hal utama dalam menentukan proses dan hasil suatu sistem pendidikan baik pada satuan pendidikan yang paling rendah hingga pendidkan nasional. Kurikulum mempunyai fungsi sebagai media atau sarana untuk mencapai tujuan sekaligus pedoman dalam pelaksanaan pembelajaran pada semua jenis dan tingkat pendidikan. Kurikulum sebagai pedoman utama dalam menentukan proses dan hasil sistem pendidikan memang memerlukan adanya upaya pengembangan secara dinamis sesuai dengan tuntutan dan perubahan yang terjadi dimasyarakat ditambah saat ini pendidikan Indonesia mengalami penurunan kualitas.

Berdasarkan data United Nations Development Program (UNDP) 2011, Indeks Pembangunan Manusia (IPM) Indonesia berada di urutan 124 dari 187 negara yang disurvei dengan indeks 0,67 persen. Sedangkan Singapura dan Malaysia mempunyai indeks yang jauh lebih tinggi yaitu 0,83 persen dan 0,86 persen. Hal ini juga terjadi pada pada indeks tingkat pendidikan tinggi Indonesia juga dinilai masih rendah yaitu 14,6 persen, berbeda dengan Singapura dan Malaysia yang sudah mempunyai indeks tingkat pendidikan yang lebih baik yaitu 28 persen dan 33 persen. Mengubah kurikulum berarti turut mengubah manusia, yaitu guru, pembina pendidikan, dan mereka yang mengasuh pendidikan, maka dari itu perubahan kurikulum dianggap sebagai perubahan sosial [2].

Kebijakan mengenai pendidikan memang menjadi sauatu perangkat yang strategis untuk dimanfaatkan dalam suatu kepentingan untuk membentuk perilaku pedagogis peserta didik menjadi tidak seimbang. Kebijakan pemerintah dalam hal pendidikan di Indonesia memang tidak dapat dipisahkan bahkan bisa dikatakan cenderung berhubungan dengan kostelasi kekuasaan atau ajang pengaruh kekuasaan, sehingga arah dan kebijakan atas pendidikan hanya ditentukan oleh keputusan pemegang kekuasaan negara. Akhirnya kajian mengenai pengembangan pendidikan lambat laun akan menjadi jenuh serta kehilangan relevansi dalam meningkatakn kualitas dan mutu pendidikan. Dikaitkan dengan kurikulum, Menurut [3] mengatakan bahwa kebijakan pemerintah terkait pendidikan saat ini merupakan bentuk pemaksaan dan tekanan yang mengerikan jika dibandingkan dengan bentuk pemaksaan lain. Kesemua hal tersebut dikarenakan muatan terhadap kebijakan yang diterapkan dalam pendidikan di Indonesia masih banyak konstelasi kekuasaan ketika menyusunya.

Terkait dengan perubahan kurikulum, Indonesia mempunyai permasalahan yang sampai saat ini masih menjadi problematika nasional yaitu perubahan kurikulum yang terjadi di Indonesia berubah dengan begitu cepat, bahkan pelaku pendidikan di Indonesia sudah begitu fasih dalam berbagai perubahan kurikulum itu sendiri. Perubahan yang telah dilakukan pemerintah Indonesia khsusnya pasca reformasi adalah Kurikulum Berbasis Kompetensi tahun 2004, berlanjut pada kurikulum 2006 dari kurikulum 2006 diganti ke kurikulum 2008 hingga yang terbaru disebut dengan kurikulum 2013. Perubahan-perubahan kurikulum yang begitu singkat dan cenderung terburu-buru ini memunculkan anggapan oleh masyarakat khususnya pelaku pendidikan berupa pernyataan ganti mentri, ganti kurikulum. Situasi yang terjadi tatkala ada pergantian kurikulum ternyata mempunyai dampak sistemik pada pembelajaran, khususnya dalam 
pembelajaran bahasa dan sastra Indonesia. Mata pelajaran bahasa dan sastra Indonesia merupakan salah satu mata pelajaran wajib di Indonesia. Terkait dengan kebijakankebijakan yang dilakukan pemerintah, secara tidak langsung juga berdampak pada bagaimana pembelajaran Bahasa dan Sastra Indonesia dilaksanakan pada setiap jenjang pendidikan.

Guru sebagai ujung tombak kemajuan pendidikan, guna meningkatkan mutu pendidikan yang sesuai dengan tujuan pendidikan nasional. Guru juga sebagai salah satu faktor penentu berhasil atau tidaknya proses pembelajaran. Keberhasilan pembelajaran sangat ditentukan oleh bagaimana guru menyampaikan pelajaran bagi peserta didik. Namun akhir-akhir ini guru menjadi bahan sorotan terkait dengan pelaksanaan kurikulum yang ada di Indonesia. Adapun kendala Kendala dari guru meliputi pembuatan media pembelajaran, pemahaman guru, pemaduan antarmuatan pelajaran dalam pembelajaran tematik, dan penguasan teknologi informasi [4]. Selain itu, kurangnya profesionalisme guru menjadi topik pembicaraan yang sering diangkat diberbagai seminar ataupun penelitian yang dilakukan seperti halnya pada penelitan yang dilakukan oleh oleh United Nations Education, Scientific and Cultural Organization (UNESCO) yang di kutip dari [5] menyatakan bahwa peringkat kualitas para guru, berada pada level 14 dari 14 negara berkembang. Hal tersebut menjadi salah satu alasan pemerintah untuk memunculkan kebijakan tentang suatu program yang akan menambah kulaitas guru yaitu program Pendidikan Profesional Guru atau dikenal sebagai PPG. PPG sendiri merupakan program baru yang dimunculkan pemerintah yang bertujuan untuk meningkatkan profesinalisme guru baik dalam administrasi maupun dalam pembelajaran dikelas.
Pemerintah memandang bahwa guru saat ini perlu diarahkan menjadi guru yang profesional sehingga muncul suatu wacana bahwa guru profesioanal adalah guru yang telah mendapatkan sertifikat pendidik sehingga mempunyai kualifikasi mengajar. Permasalahan yang muncul dalam hal tersebut adalah apakah dengan adanya program PPG, dapat meningkatkan kualitas guru sehingga dapat memberikan pembelajaran yang sesuai dengan kebutuhan peserta didik dan dapat mendukung keberhasilan kurikulum yang telah ditetapkan saat ini. Ataukah melalui programi ini hanya sekedar program untuk melegalkan kepentingan pengampu kekuasaan.

Berdasarkan fenomena tersebut, penulis mencoba menelusuri kebijakan pergantian kurikulum dan program pendidikan profesi guru secara teoritis dan praktis, apakah kedua kebijakan tersebut apakah penuh dengan konstelasi kekuasaan? Atau apakah dengan pergantian kurikulum serta program pendidikan profesi guru akan mempengaruhi mutu dan kualitas atau malah mereduksi pendidikan khususnya dalam pendidikan bahasa dan sastra Indonesia? Pentingnya pembahasan dan analisis dalam tulisan ini adalah agar pembaca mengetahui bahwa merancang kurikulum atau kebijakan lain seperti program pendidikan profesi guru tidak dapat dilepaskan dari kepentingan individual, kelompok, maupun lembaga negara.

\section{METODE}

Metode yang digunakan dalam penelitian ini adalah kualitaif deskriptif. Jenis kualitaif fenomenologi dengan melihat data berupa dokumen dan wawancara dengan pengelola PPG. Studi dokumen dilakulan bersama tim peneliti dengan diskusi FGD dan triangulasi data. Peneliti menangkap fenomena komperhensif dalam proses pelaksanaan 
PPG, peneliti merupakan pengurus PPG di Universitas Sanata Dharma Yogyakarta.

\section{HASIL DAN PEMBAHASAN \\ Kurikulum dan Konstelasi Kekuasaan}

Dilihat dari sejarahnya, kritik terhadap kurikulum ini sudah sejak lama didengungkan. Kritik terhadap kurikulum ini berawal dari kurikulum 1975, 1984, 1994. Kritik yang dilakukan pada ketiga kurikulum ini terkait dengan materi yang terlalu padat sehingga membuat proses pembelajaran kurang memperhatikan aspek afektif dan psikolotorik pada peserta didik. Pada era tersebut mata pelajaran bahasa dan sastra Indonesia dimasukan materi sastra daerah. Secara konseptual, ide tersebut bagus karena dapat mengakomodasi potensi-potensi lokal yang belum terakomodir dalam kurikulum nasional pada saat itu, namun implementasinya materi pelajaran bahasa khususnya sastra kurikulum yang belum tersususn dengan baik juga menjadi salah satu masalah yang dihadapi oleh guru mata pelajaran bahasa dan sastra Indonesia [6]. Kebijakankebijakan pemerintah pada saat itu yang cenderung terpusat membuat kontekstualitas dalam pembelajaran tidak dapat muncul dalam pembelajaran. Hal tersebut tidak dapat dilepaskan dari konstelasi kekuasaan birokrasi dalam implementasi kurikulum pada saat itu.

Kekuasaan dapat dipahami sebagai suatu yang melanggengkan relasi kekuatan yang membentuk sistem rantai dari relasi tertenu atau merupakan strategi yang kompleks dalam suatu masyarakat dengan mekanisme tertentu[7]. Jadi dengan demikian, kita dapat memahami bahwa suatu kekuasaan bekerja pada pemerintahan. Kurikulum nasional menjadi salah satu dari kekuasaan pemerintah itu sendiri. Sistem yang padat dan rumit dari kekuasaan tersebut, dapat disebut sebagai konstelasi kekuasaan. Bagaimana dengan Kurikulum 2004 (KBK), kurikulum 2008 (KTSP) serta
Kurikulum 2013 apakah termasuk dalam kostelasi kekuasaan?

Kurikulum Berbasis Kompetensi atau dikenal sebagai kurikulum KBK adalah suatu model kurikulum yang ada di Indonesia sebagai dampak dari pelaksanaan dari Undang-Undang Nomor 22 tahun 1999 mengenai pemerintahan daerah, UndangUndang Nomor 25 tahunn 2000 mengenai kewenangan Pemerintah dan Kewenangan Provinsi sebagai Daerah Otonomi dan Tap MPR No. IV/MPR/1999 mengenai Arah Kebijakan Pendidikan di Masa Depan. Pemberlakukan KBK merupakan suatu bentuk inovasi kurikulum. KBK juga merupakan semangat dari refomrasi pendidikan [8]. Rumusan dari kurikulum KBK ini diawali oleh pengeluaran draft KBK pada tahun 2000. Inti dari draft KBK itu adalah memperbaiki dan mengganti kurikulum 1994 yang syarat akan kepadatan materi serta kurangnya interaksi antara guru dan siswa. Pada kurikulum KBK ini peserta didik dijadikan sebagai pusat perhatian dalam kegiatan pembelajaran, kemampuan pribadi dari masing-masing anak menjadi pertimbangan pertama guru untuk melakukan sesuatu di kelas. Hubungan yang terjadi dalam pembelajaran dalam kurikulum KBK merupakan hubungan yang dialogis sehingga peserta didik dapat aktif bertanya dan memberikan informasi terkait pembahasan dalam pembelajaran didalam kelas. Peran guru disini lebih kepada fasilitator yang membawa peserta didik dalam mengeksplorasi materi dalam pembelajaran.

Kemunculan dari KBK ini bukan tanpa masalah dikutip dari Kedaulatan rakyat, 16 Mei 2006 [9] perubahan yang terjadi pada kurikulum KBK menimbulkan "kebingungan" bagi pelaku pendidikan baik itu guru maupun peserta didik. Sehingga menimbulkan pernyataan bahwa dengan adanya kurikulum KBK ini peserta didik seolah dijadikan percobaan bagi pemerintah 
dalam menemukan kurikulum yang mempunyai pengaruh yang lebih kepada mutu pendidikan. Jadi belum genap satu tahun kurikulum ini berjalan, sudah diusulkan untuk mengganti kurikulum dengan kurikulum lain. Selain itu, dengan adanya perubahaan kurikulum tersebut secara tidak langsung juga memberikan kebijakan terkait dengan buku pegangaan bagi siswa, sehingga dengan adanya kebijakan tersebut mempunyai kesan bahwa pergantian kurikulum ini menjadi sebuah ladang bisnis bagi pihak-pihak tertentu.

Sebagai penyempurnaan kurikulum KBK dan KTSP, Mentri Pendidikan dan Kebudayaan saat itu Muhammad Nuh memunculkan kurikulum baru pengganti KTSP yakni kurikulum 2013. Dasar pemikiran munculnya kurikulum 2013 adalah untuk menyiapkan generasi penerus yang mempunyai karakter kebangsaan yang kuat dan memiliki daya persaingan yang sejajar dengan negara seperti Finlandia, Singapura, Cina, dan Amerika Serikat. Namun belum sempat satu tahun berjalan, Muncul kebijakan baru dari Menteri Pendidikan Kebudayaan yang baru yaitu Anies Baswedan melalui Surat Edaran Mendukbud Nomor 179342/MPK/KR/2014. Surat tersebut berisi bahwa kurikulum dikembalikan ke kurikulum KTSP dan bagi lembaga pendidikan yang sudah menggunakan dan tetap menggunakan Kurikulum 2013 dipersilahkan untuk dilanjutkan. Hal tersebut secara tidak langsung juga menimbulkan kebingungan dari para pelaku pendidikan khususnya peserta didik.

Sebelum kurikulum disosialisasikan, diimplementasikan dan diberlakukan di sekolah, sebenarnya kurikulum telah diberikan banyak sumbangan pemikiran baik dari stakholder pendidikan dan juga para ahli kurikulum. Selain itu kurikulum yang akan diberlakukan juga sudah melaluiuji publik. Namun permasalahannya adalah pengampu kekuasaan yang tidak konsisten dalam membuat kebijakan pendidikan serta adanya konstelasi politik dan kepentingan dalam memutuskan kebijakan dalam penerapan kurikulum membuat arah dari tujuan kurikulum itu sendiri tidak tercapai.

Tidak dapat dipungkiri dalam suatu sistem pendidikan sudah pasti mempunyai muatan politik dalam setiap aktifitasnya seperti halnya yang diungkapkan oleh Agus yang menyatakan bahwa pendidikan tidak dapat dipisahkan dari konteks sosial, kultural, ekonomi, dan politik. Institusi pendidikan sebenarnya merupakan institusi yang tidak independen dan bebas dari berbagai kepentingan, namun justru menjadi bagian dari institusi sosial yang menjadi perebutan kepentingan [10].

\section{Kurikulum dan Reduksi Pendidikan}

Kurikulum di Indonesia secara politis dapat dibagi menjadi dua babak penting yaitu kurikulum sentralisasi (terpusat) dan desentralisasi (otonomi). Kurikulum sentralisasi (terpusat) yaitu kurikulum yang berjalan padda era 1950 sampai dengan 1994 sedangkan kurikulum desentralisasi (otonomi) berjalan dari diberlakukanya kurikulum 2004 atau biasa disebut kurikulum KBK sampai dengan kurikulum 2013.

\section{Kurikulum Sentralisasi (Terpusat)}

Kurikulum terpusat dalam sejarahnya telah mengalami beberapa kali perubahan kurikulum. Kurikulum 1950 sampai dengan diberlakukanya kurikulum 1975. Aspek yang diukur dalam kurikulum terbagi dalam 3 aspek yaitu aspek humanis, politik, dan budaya. Ketiga aspek tersebut dalam prakteknya diselenggarakan dengan menggunakan metode tata bahasa dan terjemahan [11]. Dari kedua kurikulum ini pembelajaran bahasa memunculkan peserta didik yang memiliki penguasaan dan wawasan teoritik yang luas dan mampu membaca buku asing secara baik, namun 
kelemahan dalam kurikulum ini adalah peserta didik tidak terampil dalam praktek berbahasa dalam masyarakat.

Sadar akan kelemahan tersebut, pemerintah mulai merubah orientasi tujuan pembelajaran dalam kurikulum 1975 sampai dengan kurikulum 1994. Orientasi tujuan pembelajaran bahasa Indonesia dalam kurikulum ini secara umum diarahkan dalam aspek praktik pragmatik. Hal ini ditunjukan dalam misi pembelajaran bahasa Indonesia yang bertujuan untuk menjadikan peserta didik memiliki wawasan yang luas dan terampil dalam berbahasa.

\section{Kurikulum Desentralisasi (Otonomi)}

Pasca Reformasi tepatnya pada tahun 2000an melalui Tap MPR No. IV/MPR/1999 mengenai Arah Kebijakan Pendidikan di Masa Depan pemerintah khsusunya Departemen Pendidikan Nasional melihat perlunya perubahan orientasi pendidikan yang menitikberatkan pada pengembangan kemampuan dan kebutuhan peserta didik dalam setiap jenjang pendidikan. Maka munculah kurikulum KBK yang diatur dalam Undang-Undang Nomor 20 Tahun 2003 mengenai Sistem Pendidikan Nasional Pasal 36 Ayat 2. Kurikulum ini muncul sebagai suatu rangkaian gerakan pembaharuan pasca reformasi yang banyak dipelopori oleh mahasiswa yang telah menggulirkan pemerintahan orde baru yang kebijakanya lebih mengedepankan pemerintahan sentralisasi dalam segala bidang termasuk bidang pendidikan. Dengan adanya revormasi ini berdampak pada perubahan visi dan misi pendidikan yang cukup radikal ini memunculkan wacana untuk membuat kurikulum baru yang sesuai dengan visi misi yang diwacanakan pasca reformasi tersebut. Seperti dijelaskan pada bab sebelumnya diawali oleh pengeluaran draft KBK pada tahun 2000 sebagai embrio perubahan kurikulum mulai digagas hingga akhirnya di tahu 2004 munculah label baru yaitu Kurikulum Berbasis Kompetensi (KBK).

Kemunculan kurikulum 2013 dianggap sebagai penyempurnaan kurikulum sebelumnya yaitu kurikulum KBK dan Kurikulum KTSP. Pada kurikulum 2013 memberikan perubahan dasar dalam pembelajaran bahasa dan sastra Indonesia. Pada kurikulum KBK dan KTSP, pembelajaran bahasa dan sastra Indonesia lebih mengutamakan keterampilan berbahasa dan bersastra, sedangkan dalam kurikulum 2013 bahasa dan sastra Indonesia digunakan sebagai sarana dalam mengembangkan kemampuan menalar. Perubahan ini dilatarbelakangi oleh suatu studi dari Trends in International Mathematics and Science Study (TIMSS) tahun 2011, hanya lima persen peserta didik Indonesia yang mampu memecahkan persoalan yang membutuhkan pemikiran, sedangkan sisanya 95 persen hanya sampai pada level menengah, yaitu memecahkan persoalan yang bersifat hafalan. Studi tersebut dianggap sebagai dasar perubahan pembelajaran bahasa dan sastra Indonesia sebagai solusi yang menjadikan bahasa sebagai penghela ilmu pengetahuan dan pembelajaran berbasis teks. Secara tidak langsung dengan adanya perubahan tersebut, materi pembelajaran bahasa dan sastra Indonesia mengalami reduksi terkait dengan kompetensi dalam pembelajaran khususnya dalam pembelajaran sastra.

Kurikulum 2013 secara tersurat dijelaskan bahwa pembelajaran sastra bertujuan agar peserta didik dapat "menikmati dan memanfaatkan karya sastra untuk memperluas wawasan, budi pekerti, serta meningkatkan pengetahuan dan kemampuan berbahasa, dan menghargai dan membanggakan sastra Indonesia sebagai khazanah budaya dan intelektual manusia Indonesia." Namun tujuan tersebut nampak tidak ada proporsi pembelajaran sastra yang cukup bahkan pembelajaran 
sastra dalam kurikulum 2013 ini cukup meprihatinkan.

\section{Pendidikan Profesi Guru dan Pengaruhnya terhadap Kebingungan Pelaksanaan Perubahan Kuriulum di Indonesia}

Perubahan kurikulum yang ada di Indonesia tentu berpengaruh terhadap pelaksanaan pembelajaran yang ada di dalam kelas. Salah satu kendala yang dihadapi dalam perubahan kurikulum ini adalah kebingungan guru dalam mengimplementasikan kurikulum yang berubah begitu cepat. Guru yang dipandang sebagai ujung tombak dalam kemajuan pendidikan akhir-akhir ini, guru dipandang kurang dalam hal profesionalisme. Untuk mengatasi kurangnya profesionalisme pemerintah sebagai pengampu kekuasaan memberikan program baru yaitu Program Pendidikan Profesi Guru (PPG). Secara eksplisit dalam penjelasan pasal 15 UU No 20/2003 tentang Sistem Pendidikan Nasional disebutkan bahwa pendidikan profesi merupakan pendidikan tinggi setelah program sarjana yang menyiapkan peserta didik untuk memiliki pekerjaan dengan persyaratan keahlian khusus. Pada pasal 10 UU. No 14 Thn 2005 tentang Guru dan Dosen juga menyebutkan bahwa kompetensi profesional guru diperoleh melalui pendidikan profesi. Adapun tujuan dari pendidikan profesi guru ini tercantum dalam UU No 20/2003 tentang Sistem Pendidikan Nasional dijelaskan bahwa Pendidikan Profesi merupakan pendidikan tinggi setelah program Sarjana yang mempersiapkan peserta memiliki pekerjaan dengan persyaratan keahlian khusus. Dengan demikian, program PPG merupakan program pendidikan yang diselenggarakan bagi lulusan S-1 Kependidikan dan S-1/D-IV NonKependidikan yang memiliki minat menjadi guru agar mereka dapat menjadi guru profesional setelah mereka memenuhi syarat-syarat tertentu sesuai dengan standar nasional pendidikan dan memperoleh sertifikat pendidik. Secara lebih rinci tujuan Program PPG yang dinyatakan dalam Peraturan Menteri Pendidikan dan Kebudayaan RI No 87 tahun 2013. Dalam pasal 2 Permendikbud RI No 87 tahun 2013 dipaparkan tujuan Program PPG adalah

1. untuk menghasilkan calon guru yang memiliki kompetensi dalam merencanakan, melaksanakan, dan menilai pembelajaran;

2. menindaklanjuti hasil penilaian dengan melakukan pembimbingan, dan pelatihan peserta didik; dan

3. mampu melakukan penelitian dan mengembangkan profesionalitas secara berkelanjutan.

Struktur kurikulum dalam program PPG mencakup lokakarya pengembangan perangkat pembelajaran, latihan mengajar melalui pembelajaran mikro, pembelajaran pada teman sejawat, dan Program Pengalaman Lapangan (PPL), serta program pengayaan bidang studi dan pedagogik. Sistem pembelajaran pada program PPG mencakup lokakarya pengembangan perangkat pembelajaran dan program pengalaman lapangan yang diselenggarakan dengan pemantauan langsung secara intensif oleh dosen pembimbing dan guru pamong yang ditugaskan khusus untuk kegiatan tersebut. Lokakarya pengembangan perangkat pembelajaran dan program pengalaman lapangan dilaksanakan dengan berorientasi pada pencapaian kompetensi merencanakan dan melaksanakan proses pembelajaran, menilai hasil pembelajaran, menindaklanjuti hasil penilaian, serta melakukan pembimbingan dan pelatihan. PPG ini terbagi menjadi dua jalur yaitu PPG prajabatan dan PPG dalam jabatan. PPG dalam jabatan Program Pendidikan Profesi Guru Dalam Jabatan adalah program pendidikan yang diselenggarakan (1) Bagi guru pegawai negeri sipil dan guru bukan pegawai negeri sipil yang sudah mengajar pada satuan pendidikan, baik yang 
diselenggarakan pemerintah pusat, pemerintah daerah, maupun masyarakat penyelenggara pendidikan yang sudah mempunyai perjanjian kerja atau kesepakatan kerja bersama. (2) Memiliki kualifikasi akademik sarjana (S-1) atau diploma empat (D-IV). (3) Guru dalam Jabatan atau pegawai negeri sipil yang mendapatkan tugas mengajar yang sudah diangkat sampai dengan akhir tahun 2015 (SK Bupati untuk guru honorer/GTT). (4) Mempunyai Nomor Unik Pendidik dan Tenaga Kependidikan (NUPTK), Berusia maksimal 58 tahun. (4) Terdaftar pada Dapodik dan terundang lewat akun SIMPKB.

\section{Program Pendidikan Profesi Guru} Prajabatan adalah program pendidikan yang diselenggarakan untuk mempersiapkan lulusan S1 Kependidikan dan S1/DIV Nonkependidikan yang memiliki bakat dan minat menjadi guru agar menguasai kompetensi guru secara utuh sesuai dengan standar nasional pendidikan sehingga dapat memperoleh sertifikat pendidik profesional pada pendidikan anak usia dini, pendidikan dasar, dan pendidikan menengah. Calon peserta memiliki kualifikasi akademik sebagai berikut: (1) S1 Kependidikan yang sesuai dengan program pendidikan profesi yang akan ditempuh; (2) S1 Kependidikan yang serumpun dengan program pendidikan profesi yang akan ditempuh; (3)S1/DIV Nonkependidikan yang sesuai dengan program pendidikan profesi yang akan ditempuh; (4) S1/DIV Nonkependidikan serumpun dengan program pendidikan profesi yang akan ditempuh; (5) S1 Psikologi untuk program PPG pada PAUD atau SD. (6) Berusia maksimal 28 tahun dan belum menikah (bersedia tidak menikah sampai selesai studi PPG). Selain peserta dengan kriteria di atas, PPG Prajabatan juga ditujukan bagi lulusan SM-3T (Sarjana Mendidik Di Daerah Terdepan, Terluar dan Tertinggal).
Kebijakanmengenai penyelenggaraan pendidikan profesi guru ini bukan tanpa masalah. Kritik terhadap program terus didengungkan. Kritik ini terkait dengan perlukah pemberian lebel profesional terhadap guru dalam meningkatkan mutu pendidikan di Indonesia? Serta pengaruh yang ditimbulkan dari program tersebut dalam mengimplementasikan perubahan kurikulum yang terjadi dalam pendidikan Indonesia serta pengaruhnya terhadap peningkatan mutu pendidikan?

Terkait dengan profesionalitas guru perlukah profesional dalam peningkatan pendidikan bahasa dan sastra Indonesia. Para intelektual haruslah berlaku amatir bukan profesional. Amatir berasal dari kata "amor" yang mempunyai arti cinta. Jika dikaitkan dengan guru, guru harusnya menerapkan rasa cinta dari pada profesionalitas kerja karena yang dihadapi adalah pribadi peserta didik yang merupakan makhluk yang membutuhkan rasa cinta dalam setiap perkembanganya [12]. Jika seorang guru melandasi pekerjaanya dengan profesional maka guru tersebut lebih mendasarkan kepada hasrat dalam mendapatkan upah yang layak. Oleh karena itu, pemberian label guru profeisonal tidak diperlukan dalam peningkatan mutu pendidikan dikarenakan aktivitas guru dalam pembelajaran harus menjauhkan hasrat profit, melainkan didasari pada kesadaran kritis untuk perubahan social, kecintaan pada peserta didik [13].

Jika dilihat secara seksama, Program PPG baik prajabatan maupun dalam jabatan terkandung konstelasi kekuasaan di dalamnya. Hal ini dapat dilihat dari beberapa catatan pertama tidak ada tindak lanjut dari program PPG. Guru yang sudah mendapatkan sertifikat pendidik tidak lagi dipantau, jadi secara tidak langsung program ini hanya sekedar pengakuan secara formal bahwa guru tersebut telah memenuhi indikator-indikator yang 
ditetapkan dalam program tersebut. Kedua dari hasil wawancara yang dilakukan penulis didapati bahwa materi yang diberikan dalam program ini tidak berbeda dengan meteri yang diberikan di universitas, jadi keefektifan dari program tersebut oleh penulis dirasa kurang karena mengulangi hal yang sama dalam program baru. Ketiga adalah PPG prajabatan, tujuan dari ppg prajabatan tidak lain adalah untuk meningkatkan kualitas calon guru sesuai dengan indikator-indikator yang ditetapkan dalam program tersebut. Yang menadi pertanyaan adalah apakah selama ini universitas keguruan dan ilmu pendidikan tidak membekali mahasiswanya untuk menjadi guru yang berkualitas? jika memang universitas keguruan dan ilmu pendidikan tidak membekali masiswa untuk menjadi guru berkualitas, kenapa tidak memperbaiki konsep dan pembelajaran dalam perkuliahan disetiap universitas tersebut, namun malah menambah program baru. Selain itu, jika memang program tersebut efektif dalam menciptakan dan menambah kualitas lulusan guru kenapa program tersebut diterapkan dalam setiap universitas keguruan. Keempat tidak ada program sejenis di negara-negara yang maju pendidikanya seperti Finlandia, Korea Selatan, Jepang dan seterusnya. ) Kelima tes yang digunakan dalam seleksi masuk hanya menggunakan tes yang secara tidak langsung hanya mengukur tingkat kognitif saja. Keenam sama halnya dengan seleksi masuk, dalam menentukan kelulusan program PPG ini menggunakan tes Uji Kompetensi terdiri dari UTL, UTN, dan UK melalui tes CBT. Penggunaan tes tersebut menjadi sebuah pertanyaan besar, bagaimana mengukur profesionalitas guru menggunakan tes yang mayoritas mengukur tingkat kognitif saja, hanya satu kali diukur berdasarkan kinerja praktik. Ketujuh dengan adanya program tersebut secara tidak langsung perguruan tinggi yang menyelenggarakanya akan mendapatkan pendapatan lebih dari mahasiswa yang turut serta dalam program tersebut, sehingga nampak jelas bahwa program tersebut mempunyai kepentingan ekonomi. Hal tersebut dibuktikan dengan adanya begitu mahalnya program tersebut. Mahasiswa harus mengeluarkan tujuh setengah juta per semester untuk mengikuti program tersebut. Jadi dari kesemua catatan tersebut penulis menyimpulkan bahwa program PPG Tidak dapat digunakan sebagai patokan dalam meningkatkan kualitas pendidikan yang ada di Indonesia. Selain itu, program PPG ini dirasa masih banyak kepentingan serta konstelasi baik politk dan ekonomi dari penetapan program tersebut. Seperti yang dijelaskan pada bab sebelumnya bahwa kebijakan-kebijakan yang ada dalam pendidikan di Indonesia termasuk pendidikan profesi guru ini tidak dapat dilepaskan dari konstelasi politik dan kepentingan pengampu kekuasaan.

\section{SIMPULAN}

Melihat banyaknya problematika dalam pendidikan yang ada di Indoensia terkait pada perubahan kurikulum khususnya Program Pendidikan Profesi Guru, kiranya kita dapat melihat bahwa kebijakan yang dikeluarkan pemerintah masih penuh dengan adanya konstelasi kekuasan. Memang, diera modern perlu adanya kebijakan-kebijakan yang mengarahkan kepada peningkatan mutu pendidikan, namun perlu diperhatikan bahwa kebijakankebijakan tersebut harus dilakukan secara sistematis, terencana, terstruktur, dan bertujuan untuk mencapai kemajuan pendidikan nasional. Kebijakan-kebijakan yang dilakukan harusnya menghindarkan dari kepentingan kekuasaan apalagi motif ekonomi ataupun politik semata. Melihat kenyataan seperti ini, hendaknya pemerintah sebagai stakeholder pendidikan dan pengampu kebijakan atas pendidikan di Indonesia perlu menyamakan persepsi dengan semua elemen antara lain pakar pendidikan, perguruan tinggi, LSM, PGRI dan aktivis pendidikan lain yang ada di 
Indonesia agar konstelasi kekuasaan atas pendidikan dapat dihindari serta pengawasan terhadap pendidikan dapat dilakukan. Bukan tidak mungkin dengan adanya hal tersebut iklim pendidikan ideal bagi masyarakat Indonesia dapat tercapai.

\section{DAFTAR PUSTAKA}

[1] Arifin, Zainal. Konsep \& Model Pengembangan Kurikulum. Bandung: Remaja Rosdakarya. 2011.

[2] Nasution. Asas-asas Kurikulum, Jakarta: Bumi Aksara. 2009.

[3] Pora, Y. Selamat Tinggal Sekolah. Yogyakarta: MedPress. 2007.

[4] Damai. A, Rusmawan. Kendala Guru Sekolah Dasar Dalam Implementasi Kurikulum 2013. Th. XXXIV, Nomor. 3. 2015.

[5] Cuttence, P. School Innovation, Pathway to The Knowledge Society. Australia. Dept. of Education, Training and Youth Affairs Innovation and Best Practice Project Consortium. 2001.

[6] Damit, J. Problematik Pembelajaran Sastra Indonesia Kelas Viii Smp Negeri 4 Mallusetasi Kabupaten Barru (Skripsi). Makasar: Universitas Negeri Makasar. 2016.

[7] Folcault. The History of Sexuality: An Introduction, Vol. 1. New York: Vintage Books. 1990.

[8] Sanjaya, W. Pembelajaran dalam Implementasi Kurikulum Berbasis Kompetensi. Jakarta: Prenada Media. 2005.

[9] Susilo, M. Joko. Pembodohan Siswa Tersistematis. Jakarta: Perpustakaan Nasional. 2007.

[10]Nuryatno, M. Agus. Mazhab Pendidikan Kritis Menyingkap Relasi Pengetahuan Politik dan Kekuasaan. Yogyakarta: Resist Book. 2008.

[11]Burhan, Yazir. Problem Bahasa dan Pengajaran Bahasa Indonesia. Bandung: Percetakan Ganaco. 1971.
[12]Edward W. Representations of the Intelleectual. New York:Vintage Book. 1996.

[13] Giroux, H. Cultural Workers and The Politics of Educations. New York: Rotledge. 1992. 